\title{
A TRAJETÓRIA HISTÓRICA DO CONSELHO ESTADUAL DE EDUCAÇÃO DE MATO GROSSO DO SUL: ORGANIZAÇÃO, COMPOSIÇÃO E REPRESENTATIVIDADE
}

\author{
Nadia Bigarella ${ }^{1}$ \\ Regina Tereza Cestari de Oliveira ${ }^{2}$
}

\section{Resumo}

Este artigo analisa a formação e a trajetória do Conselho Estadual de Educação de Mato Grosso do Sul (CEE/MS) no contexto histórico da criação (1979) e construção do estado, até o período atual (2014). Com base na análise de fontes documentais (decretos, leis, mensagens à Assembleia Legislativa, atos normativos, regimento interno do CEE/MS), verificou-se a sua composição, representatividade, organização, funcionamento e as suas influências nas políticas educacionais para a educação básica. A análise permitiu evidenciar elementos da realidade socioeconômica e política que direcionaram a sua regulamentação e as condições concretas para o desempenho das suas funções e suas responsabilidades como órgão de gestão do sistema de ensino, ressaltando o seu caráter consultivo e normativo reforçado, ao longo do tempo, pela ausência de pluralidade na sua representatividade e pela falta de revezamento de conselheiros.

Palavras-chave: Conselho estadual de educação. Estado de Mato Grosso do Sul. Gestão educacional. Legislação estadual.

\section{THE HISTORICAL TRAJECTORY OF THE MATO GROSSO DO SUL STATE BOARD OF EDUCATION: ORGANIZATION, COMPOSITION AND REPRESENTATIVENESS}

\begin{abstract}
This article analyzes the Mato Grosso do Sul State Board of Education (CEE/ MS) formation and trajectory in the creative context (1979) and construction of the state, until the current period (2014). With based on the documentary sources, analyses (decrees, laws, messages to the Legislative Assembly, normative acts, internal rules of the CEE/ MS), it verified his composition, representation, organization, operation and his influences in the political education for the basic education. The analysis allowed evidence elements of the socioeconomic and political reality that addressed his regulation and the concrete conditions for the performance this of his functions and his responsibilities like organ of management of the system of education, highlighting his consultative and normative character reinforced, to the length of the time, by the absence of plurality in his representativeness and by the fault of relay of advisers.
\end{abstract}


Keywords: State board of education. State of Mato Grosso do Sul. Educational management. State law.

\title{
LA TRAYECTORIA HISTÓRICA DEL CONSEJO PROVINCIAL DE EDUCACIÓN DE MATO GRUESODEL SUR: ORGANIZAÇÃO, COMPOSICIÓN Y REPRESENTATIVIDAD
}

\begin{abstract}
Resumen
Este artículo analiza la formación y la trayectoria del Consejo Estatal de Educación de Mato Grosso do Sul (CEE / MS) en el contexto de la creación (1979) y construcción del estado, hasta el período actual (2014). Con base en el análisis de fuentes documentales (decretos, leyes, mensajes a la Asamblea Legislativa, actos normativos, regimiento interno del CEE / MS), se verificó su composición, representatividad, organización, funcionamiento y sus influencias en las políticas educacionales para la educación básica. El análisis permitió evidenciar elementos de la realidad socioeconómica y política que direccionaron su reglamentación y las condiciones concretas para el desempeño de sus funciones y suyas responsabilidades como órgano de gestión del sistema de enseñanza, resaltando su carácter consultivo y normativo reforzado, al largo del tiempo, por la ausencia de pluralidad en su representatividad y por la falta de revezamento de consejeros.
\end{abstract}

Palabras clave: Consejo estadual de educación. Estado de Mato Gruesso del Sur. Gestión educacional. Legislación providencial.

\section{INTRODUÇÃO}

Este artigo tem por objetivo analisar a formação e a trajetória do Conselho Estadual de Educação de Mato Grosso do Sul, destacando os principais elementos da realidade socioeconômica e política que possibilitaram a constituição histórica e a regulamentação desse Conselho, desde a sua criação (1979) até o período atual (2014). Para tanto, apresentase, inicialmente, o processo de criação e instalação do Estado de Mato Grosso do Sul, no contexto nacional.

Um Conselho de educação é entendido como órgão de Estado que participa da gestão do sistema de ensino, em três frentes: a) garantia dos direitos educacionais; b) estudo dos problemas educacionais; e c) relação entre eles (direito e problemas educacionais) (Cury, 2006) e está situado na estrutura de gestão dos sistemas de ensino que têm o papel de tornar “[...] presente a expressão da vontade da sociedade na formulação das políticas, nas normas educacionais e nas decisões dos dirigentes." (CURY, 2001, p. 7). Assim, um Conselho como órgão colegiado, em última instância, é responsável pela mediação entre Estado e sociedade, na medida em que pode viabilizar a participação de vários segmentos sociais, abrangendo 


\section{Revista HIISTESIDBR On-lime}

ISSN: 1676-2584

Artigo

doi: $10.20396 /$ rho.v18i1.8645890

representantes da sociedade política (aparelho governamental) e da sociedade civil (aparelhos privados de hegemonia) ${ }^{3}$ na discussão e na formulação de políticas educacionais.

\section{CRIAÇÃO E INSTALAÇÃO OFICIAL DO ESTADO DE MATO GROSSO DO SUL}

O Estado de Mato Grosso do Sul, criado sob a égide da Constituição Federal de 1967, por determinação da Lei Complementar $n^{\circ}$ 31, de 11 de outubro de 1977, assinada pelo penúltimo Presidente da República dos governos militares, general Ernesto Geisel (1974 $1979)^{4}$, foi instalado oficialmente em primeiro de janeiro de 1979, com a posse do primeiro governador, Harry Amorim Costa (1979-1979), do partido da Aliança Renovadora Nacional (ARENA), no mesmo dia da revogação ${ }^{5}$ dos atos institucionais: Ato Institucional $n^{\circ} 1 / 1964$ - cassou o mandato dos políticos de oposição; Ato Institucional nº 2 /1965 - extinguiu os partidos existentes e estabeleceu o bipartidarismo; Ato Institucional n $\mathrm{n}^{\mathrm{o}}$ 3/1966 estabeleceu que os prefeitos de capitais, e municípios da área de segurança nacional e os governadores dos estados deveriam ser nomeados pelo governo militar; Ato Institucional $\mathrm{n}^{\circ}$ 4/1966 - obrigou o Congresso a votar o projeto da Constituição de 1967; Ato Institucional $\mathrm{n}^{\mathrm{o}}$ 5/1968 - fechou o Congresso, suspendeu garantias constitucionais e deu poder ao Executivo, poderes legais para legislar sobre todos os assuntos. (BASTOS, 2002).

Sua instalação no mesmo dia da revogação dos atos institucionais ${ }^{6}$ não foi simples coincidência, e sim uma das estratégias do governo militar para divulgar o seu projeto político, social, econômico e ideológico, de caráter desenvolvimentista e modernizador, centrado no planejamento, na ação estatal e na economia de mercado mundial, presente no II Plano de Nacional Desenvolvimento (1974-1979). Tratava-se de um plano de investimentos públicos e privados dirigidos aos setores de infraestrutura, bens de produção, energia e exportação, o qual dependia, para sua viabilização, de fontes de financiamento público e externo. (HERMANN, 2005).

Os planos dos governos militares acentuaram a concentração de renda. Com os financiamentos públicos direcionados às grandes indústrias, fazendas, construtoras, bancos e outros, os donos do capital não tiveram dificuldades para introduzi-las em seus negócios. Isso significou, para o capital, lucros cada vez maiores, mas, para os trabalhadores, houve a desvalorização do trabalho, o desemprego e o aumento do subemprego. Não bastasse isso, em meados da década de 1970, uma conjuntura mundial desfavorável, reflexo da crise do petróleo, inflacionou os preços de todos os produtos de consumo. A economia mundial foi comprometida pelos efeitos da crise, contudo o Estado brasileiro foi um dos mais afetados, porque importava $80 \%$ do petróleo que consumia. (IANNI, 1986).

De acordo com Ianni (1986), no período de 1964 a 1985, as políticas nacionais apresentaram uma combinação de medidas: política de planejamento voltada para o 
desenvolvimento industrial, principalmente das automobilísticas, políticas de defesa nacional, relacionadas à ordem e estabilidade econômica e social. Importante relatar que todas as decisões eram centralizadas no Poder Executivo, afastando-se, assim, qualquer possibilidade de participação dos segmentos sociais no debate político, uma vez que, na visão dos governos do período, além da postura subversiva, eram os trabalhadores que contribuíam para o aumento da inflação.

Diante de uma conjuntura de crise econômica e inflacionária e dificuldades de se efetuar uma aliança social e política para continuar mantendo o desenvolvimento acelerado do país, a opção mais viável naquele momento, na análise do grupo que integrava o governo militar, foi elaborar políticas para modernizar a agricultura e para favorecer o capital privado, tanto o nacional, quanto o estrangeiro, tendo em vista a exportação. Por isso, o desenvolvimento extensivo e intensivo do capitalismo no campo foi priorizado. (IANNI, 1986).

Conforme expresso no documento II PND/1974-1979, tratava-se de exigir muito mais do setor agropecuário, que deveria desempenhar novo papel na estratégia nacional de desenvolvimento, mediante o fornecimento de alimentos e de matérias-primas para o abastecimento interno e para a exportação e, com isso, acabar de vez com a inflação.

Para tal dimensão, seria necessária a ocupação de novas áreas territoriais, principalmente, as do Centro-Oeste e da Amazônia, como uma estratégia "[...] importante de expansão da agricultura, dada a existência de terras relativamente férteis para deslocamento da fronteira agrícola, e tendo em vista o gigantesco sistema viário já construído.” (BRASIL, 1974, p. 33-34).

Todas as ações tinham como finalidade ocupar a maior parte da extensão territorial, de modo mais lucrativo, para dinamizar e modernizar a agropecuária e impulsionar o crescimento das cidades. Mas tudo isso foi planejado sem preocupação com as políticas de urbanização, igualdade social e melhor distribuição de renda. A preocupação era a manutenção do capitalismo, ou seja, "[...] manter a macroeconomia em ordem e cuidar para que o ambiente econômico seja market friendly (literalmente: amigável ao mercado) [...]". (SINGER, 1998, p. 131).

No discurso, os governos retomaram as raízes históricas da vocação agrícola do país e justificaram a necessidade de disponibilizar mais empréstimos para os grandes agricultores e/ou empresários agrícolas. Com isso, buscava-se aumentar a produção de alimentos mediante o aproveitamento racional de um amplo espaço com terras úmidas e irrigáveis das zonas áridas, especialmente, a Amazônia e o Centro-Oeste, conforme prescreveu o II PND, elaborado no governo Ernesto Geisel. (BRASIL, 1974). Esses benefícios, segundo o mesmo Plano, seriam financiados por diversos órgãos de planejamento regionais, tal como a Superintendência para a Valorização Econômica da Amazônia (SPVEA) e a Superintendência do Desenvolvimento do Centro-Oeste (SUDECO) que, com o Banco 
Nacional de Desenvolvimento Econômico e Social (BNDES) e o Banco Mundial (BM), seriam responsáveis pelo financiamento e pelo planejamento de instalação do Estado de Mato Grosso do Sul e dos projetos voltados para a infraestrutura econômica, de energia e transporte. (BRASIL, 1974).

A decisão de criar Mato Grosso do Sul foi influenciada pelos estudos do general Golbery do Couto e Silva, fundamentados na doutrina McNamara, de Robert McNamara, Secretário de Defesa dos Estados Unidos e presidente do Banco Mundial, entre os anos de 1968 e 1981. Essa doutrina, segundo Ianni (1986), baseava-se na questão primária do medo advindo da insegurança de uma sociedade que se modernizava rapidamente. Ainda de acordo com Ianni (1986, p. 64), a doutrina de Robert McNamara, por afirmar que a "segurança é desenvolvimento, e sem desenvolvimento não há segurança", ganhou desdobramentos no Brasil, durante os governos militares (1964-1985), pois associava os conceitos desenvolvimento e segurança nacional à construção de um projeto de manutenção do poder militar.

Outra determinação era transformar Mato Grosso do Sul em um Estado modelo com um novo "método de governo" e novas técnicas de administração pública, que transformassem "[...] problemas políticos, sociais e econômicos em problemas administrativos" e que perpetuassem o projeto político e ideológico do regime militar. (FERNANDES, 1996, p. 69). Por isso, o Estado seria construído com uma estrutura enxuta, com um número reduzido de fundações e setores administrativos descentralizados (diretos e indiretos), capazes de atender todas as suas obrigações e responsabilidades, e aos municípios.

Na conjuntura nacional, segundo Rocha (1992), a criação de um novo Estado estava relacionada às ideias do fortalecimento do projeto geopolítico do governo militar, à inserção do Brasil no modelo de economia aberta, como um grande exportador de grãos, ou seja, fazer o país produzir mais e importar menos; inserir o setor agropecuário a serviço das indústrias; a área rural como suporte do crescimento urbano; fixação do homem no campo e incentivo fiscal ao pequeno e médio empresário. (BRASIL, 1974).

Enquanto na conjuntura regional, ainda de acordo com Rocha (1992), sem a participação popular e sem uma formação de representantes sul-mato-grossenses para acompanhar as discussões sobre a divisão do Estado, a criação deste veio ao encontro dos interesses de dois grupos políticos locais, do mesmo partido de situação (ARENA), que perceberam a possibilidade de novos espaços e mais prestígio político: os ruralistas, cujos interesses estavam voltados para a atividade econômica mais tradicional do sul de Mato Grosso, ou seja, a pecuária, e o outro, com interesses voltados para a industrialização e a introdução de tecnologia mais avançada na agricultura do Estado. Porém ambos os grupos eram proprietários de grandes latifúndios e políticos de uma determinada região que, juntos, formavam uma sociedade agropecuária que lutava para impor os seus valores conservadores, 
clientelistas, patrimonialistas que garantissem a manutenção da sua dominação e o controle do Estado. (BIGARELLA, 2004).

Do ângulo político, as disputas entre os grupos adversários que queriam assumir o controle da administração do Estado acirraram-se com o advento da criação do Estado, principalmente, nos primeiros quatro anos após a divisão (1979 a 1982) porque, nesse período, a escolha do governador era feita por meio de nomeação do governo federal. Fato que provocou uma sucessão de governadores, que somente cessou com a eleição do governador Wilson Barbosa Martins, do PMDB, em 1982, que tomou posse em 15 de março de 1983. (ROCHA, 1992).

O modelo administrativo foi determinado pelo Decreto-Lei $\mathrm{n}^{\circ} 1$, de $1^{\circ}$ de janeiro de 1979, que estabeleceu a organização básica do Estado de Mato Grosso do Sul, conforme apresentado a seguir.

\author{
Art. 23 - O Poder Executivo compreenderá: \\ I - órgãos da Administração Pública Direta; \\ II - entidades da Administração Pública Indireta. \\ $\S 1^{\circ}$ - Constituem entidades da Administração Pública Indireta, na forma da \\ legislação federal e estadual, que lhes for aplicável: \\ I - autarquia; \\ II - empresa pública; \\ III - sociedade de economia mista. (MATO GROSSO DO SUL, 1979c, p. 5).
}

Em discurso oficial, o primeiro governador Harry Amorim Costa (1979-1979) faz uma relação dessa forma compacta do Poder Executivo, com novas técnicas em administração pública. Nas palavras dele, essa organização básica do Poder Executivo deveria seguir as mesmas "[...] diretrizes recomendadas para o desenvolvimento organizacional [...]”. (COSTA, 1979a, p. 3).

Ainda de acordo com o discurso oficial do governador Harry Amorim Costa, a organização estatal deveria assim observar que

\footnotetext{
[...] estrutura básica é normativa, orientadora, coordenadora e avaliativa, e, por isso mesmo leve e dinâmica.

A ação executiva, através de órgão vinculado, é descentralizada por regionalização, em amplo apoio aos Municípios.

Setores afins, nas áreas psicossocial e econômica, são gerenciados de forma integrada. (COSTA, 1979b, p. 4).
}

A ênfase, então, seria nos resultados (fins), não nos procedimentos (meios), como pedia o modelo de gestão burocrática utilizado pelo Estado brasileiro que, na visão do governador Harry Amorim Costa, já estava ultrapassado. (COSTA, 1979a). Assim, enquanto o foco da burocracia estava nos trâmites legais, o gerencialismo foi voltado para a eficiência em todos os escalões governamentais.

Conforme o substrato do Decreto-Lei $\mathrm{n}^{\mathrm{o}} 1$, de $1^{\mathrm{o}}$ de janeiro de 1979: 


\section{Revista HIIST'TEIDBR On-line}

Art. $8^{\circ}$ - São atribuições dos Secretários de Estado, como auxiliares diretos do Governador, exercer, na área de sua competência, a orientação, coordenação e supervisão dos órgãos e entidades da administração estadual, bem como desempenhar as funções que lhes forem especificamente cometidas pelo Governador do Estado, podendo delegar competência a seus subordinados (MATO GROSSO DO SUL, 1979c, s.p).

Nessa concepção, a administração estadual foi apresentada como um novo e moderno modelo de gestão pública, que queria modificar os critérios de aplicação do controle dos serviços públicos, as relações estabelecidas com os servidores e alterar, também, a própria atuação da administração, que passaria a enfatizar a eficiência, tendo em vista harmonizar os interesses das diversas áreas e racionalizar a utilização de recursos financeiros e administrativos. (MATO GROSSO DO SUL, 1979c, 1979d).

O modelo de gestão apresentado pelo primeiro governo teve forte influência do Decreto-Lei $\mathrm{n}^{\circ}$ 200/1967 (BRASIL, 1967b), assinado pelo presidente da República Humberto Castelo Branco (1964-1967). Esse modelo, voltado para o desenvolvimento e segurança nacional, fixou os princípios fundamentais das atividades administrativas dos governos militares. Esse Decreto-Lei assumiu uma feição essencialmente pragmática e vinculada aos estritos preceitos normativos e centralizadores, apesar de o art. 10, $\S 1^{\circ}$, ter prescrito que a administração pública deveria ser descentralizada em três áreas principais e de ordem:

a) interna: da Administração Central para outros órgãos de execução;

b) externa, mediante convênio: da Administração Central para outras unidades federadas;

c) parcerias público/privadas: Administração Central para o setor privado, mediante contratos e/ou concessões. (BRASIL, 1967b, art. 10).

O que aconteceu, tanto no âmbito nacional quanto no estadual, foi a submissão dos órgãos e entes federados descentralizados às normas elaboradas pela administração central, acarretando perda de autonomia administrativa nos moldes do Decreto-Lei $\mathrm{n}^{\mathbf{0}}$ 200/. (BRASIL, 1967b). Em face à observância dessas normas, dos aspectos técnicos e científicos e em função das exigências políticas da época, buscou-se promover a transferência das atividades de produção de bens e serviços para autarquias, fundações, empresas privadas e sociedades de economia mista, bem como a instituição de racionalidade administrativa, planejamento, orçamento, descentralização e controle de resultados como princípios básicos da gestão estatal. (MATO GROSSO DO SUL, 1979c, 1979d).

Nas décadas de 1960 e 1970, iniciou-se uma campanha de valorização dos modelos de gestão usados pelo setor privado para serem adotados no setor público (ABRUCIO, 1997), surgida em decorrência da crise do petróleo de 1973 e 1979, do movimento de globalização e das transformações tecnológicas em curso desde a década de 1970, alterarando a lógica do setor produtivo e também a ideia de gerenciamento estatal, refirmada no II PND 1975-1979, a da gestão gerencial no serviço público. 
A perspectiva inicial do modelo gerencial, com forte tendência economicista, com excessiva hierarquização e com planejamento centralizado no Poder Executivo é que serviu de base para a construção da organização da administração do Estado de Mato Grosso do Sul, como instrumento operacional do Poder Executivo. Apresentada no Decreto-Lei ${ }^{\circ}$ 1/1979 (MATO GROSSO DO SUL, 1979c) e no Decreto-Lei n 2/1979 (MATO GROSSO DO SUL, 1979d), como um modelo moderno, que buscava redução de custos, controle e racionalidade dos gastos públicos, principalmente, com a redução de pessoal, a qualidade dos serviços e o aumento da eficiência e produtividade.

Outra característica foi a tensão entre descentralização e centralização das decisões, aqui tomadas pelo chefe do Poder Executivo (governador do Estado), sem discussões com outras instâncias. Assim, a descentralização na gestão pública ficou restrita; a transferência de tarefas da administração direta para indireta não se traduziu em distribuição de poder entre os órgãos que integravam o Sistema Executivo de Desenvolvimento de Recursos Humanos (SEDRH), consistiu apenas na repartição de funções e responsabilidades entre os vários órgãos da mesma administração centralizada, sem quebra de hierarquia, sem regras sobre alocação de recursos e sem autonomia orgânica aos componentes institucionais, mantendo, assim, o poder de decisão no Poder Executivo.

Assim, constituiu uma organização burocrática, sem autonomia e com o poder de decidir, a vigilância e o controle concentrados no Poder Executivo, que fixava os limites da autonomia de todos os outros órgãos do sistema. Foi esse pensamento que levou à idealização do modelo de organização estatal apresentada pelo primeiro governo, como solução para os problemas políticos, econômicos, administrativos e como símbolo da modernização e instrumento contra o patrimonialismo, corrupção e clientelismo.

Tanto os políticos da ARENA quanto os do Movimento Democrático Brasileiro (MDB), ainda de acordo com Bigarella (2004), reclamavam de todo o aparato governamental que estava repleto de funcionários públicos de alto escalão vindos de Brasília e do Rio Grande do Sul, que, além dos altos salários, também podiam acumular duas a três funções e receber os valores dos cargos comissionados, conforme explicitava o Decreto-Lei ${ }^{\circ} 15$, de $1^{\circ}$ de janeiro de 1979, enquanto outros setores não tinham recursos para funcionar, como a educação, a saúde e assistência social.

Essa situação descontentou os deputados sul-mato-grossenses, que já estavam insatisfeitos com a nomeação do Governador Harry Amorim Costa, e que aproveitaram a extinção do AI-5 para protestar e tornar público seu descontentamento nas seções da Assembleia Constituinte, em discursos contra a nomeação do governador, da sua equipe de técnicos e excesso de gastos e poder dado a um grupo que desconhecia a realidade local.

Nesse contexto, o primeiro governo não obteve sucesso, pois não modernizou nem descentralizou a estrutura do Estado. Tampouco conseguiu apresentar um programa na área social, deixando o governo após ser exonerado junto com o grupo de técnicos, sem nenhuma 
ação ou projeto iniciado na área educacional, por falta de um programa educacional na agenda governamental, tomada pela vontade de implantar um novo método de governo, e pelas dificuldades políticas enfrentadas entre os deputados e o governo.

Assim, o Estado de Mato Grosso do Sul trouxe, desde seu início, a descontinuidade das ações, os planos inacabados, o embate entre os políticos no processo de consolidação do Estado, acirrando cada vez mais as disputas entre grupos pela posse da administração estatal. Isso resultou no encerramento da proposta dos planos da construção de um "Estado Modelo". Nesse contexto, foi criado o Conselho Estadual de Educação de Mato Grosso do Sul, conforme será abordado na seção seguinte.

\section{CONSELHO ESTADUAL DE EDUCAÇÃO DE MATO GROSSO DO SUL: 1979-1990}

O Conselho Estadual de Educação de Mato Grosso do Sul foi criado no governo Harry Amorim Costa, com funções normativas e de supervisão, pelo Decreto-Lei $n^{\circ} 8$, de $1^{\circ}$ de janeiro de 1979, que estabeleceu as diretrizes para o sistema administrativo do Estado sul-mato-grossense (MATO GROSSO DO SUL, 1979e) e foi instituído para atuar de forma suplementar ao Conselho de âmbito federal, sob o amparo legal na Lei no 5.692/1971, que fixava as diretrizes e bases para o ensino de $1^{\circ}$ e $2^{\circ}$ graus e também, segundo Saviani (2006, p. 116), para "[...] ajustar a educação brasileira à ruptura política perpetrada pelo Governo Militar de 1964."

Tal como os outros conselhos estaduais de educação do Brasil, o CEE/MS também recebeu atribuições fiscalizadoras, de natureza econômico-financeira, encargo, até então, atribuído à Superintendência Nacional de Abastecimento (SUNAB); conforme o DecretoLei $n^{\circ} 532 / 1969$, por exemplo, passou a ser de responsabilidade do Conselho Federal de Educação, dos conselhos estaduais de educação e do Conselho de Educação do Distrito Federal, no âmbito das respectivas competências e jurisdições, "[...] a fixação e o reajuste de anuidades, taxas e demais contribuições correspondentes aos serviços educacionais, prestados pelos estabelecimentos federais, estaduais, municipais e particulares." (BRASIL, 1969, p. 1).

O CEE/MS, com características burocráticas e racionais, com tendência normativa, técnica, teve como primeiro presidente um médico militar, Lécio Gomes de Souza (1979). Com representação da iniciativa privada e de chefes de departamentos da SEDRH (1979), o número de membros foi definido no Art. $2^{\circ}$, do Decreto $n^{\circ}$ 83/1979, sua composição e funcionamento: "Na escolha dos membros do Conselho Estadual de Educação, o Governador do Estado levará em consideração a necessidade de neles serem devidamente representados os diversos graus de ensino e o magistério oficial e particular." (MATO GROSSO DO SUL, 1979a). 
Inicialmente, como órgão colegiado e de governo, subordinado ao SEDRH, com o objetivo de "contribuir para a promoção de melhores níveis sanitários, educacionais, culturais, de aptidão física e desportiva, de aprimoramento profissional e de bem-estar da população do Estado", que abrangia a Fundação de Educação de Mato Grosso do Sul, que tinha por "[...] finalidade planejar, promover e executar atividades relacionadas com o ensino [...]" (MATO GROSSO DO SUL, 1979b Art. $1^{\circ} ; 7^{\circ}$ ), o CEE/MS mostrava, nas suas atribuições e nos critérios de escolha dos conselheiros, uma forma de dependência ao Poder Executivo, conforme artigos destacados a seguir:

\footnotetext{
Art. $1^{\circ}$ - O Conselho Estadual de Educação, criado pelo Decreto- Lei $n^{\circ} 8$, de $1^{\circ}$ de janeiro de 1979, é composto de doze membros efetivos e três suplentes, nomeados pelo Governador do Estado, dentre pessoas de notório saber e experiência em assunto de Educação.

$\S 1^{\circ}$ - Ao ser instituído o Conselho, um terço de seus membros terá mandato de dois anos e dois terços de quatro anos.

$\S 2^{\circ}$ - A renovação do Conselho far-se-á bienal e alternadamente, por um e dois terços de seus membros.

$\S 3^{\circ}-\mathrm{O}$ Conselheiro, em seus impedimentos, será substituído por um dos suplentes.

$\S 4^{\circ}$ - Ocorrendo vaga no Conselho, será nomeado novo Conselheiro que completará o mandato do antecessor.

Art. $2^{\circ}$ - Na escolha dos membros do Conselho Estadual de Educação, o

Governador do Estado levará em consideração a necessidade de neles serem devidamente representados os diversos graus de ensino e o magistério oficial e particular. (MATO GROSSO DO SUL, 1979b).
}

Assim como os conselhos estaduais do Brasil, a organização e a constituição do CEE/MS seguiram a Lei de Diretrizes e Bases $n^{\circ}$ 4.024/1961 (LDB 4.024/1961), Lei $n^{\circ}$ 5.692/1971 e os fundamentos da CF de 1967 (BRASIL, 1967a). O Art. 10, da LDB n ${ }^{\circ}$ 4.024/1961, mantido na Lei $n^{\circ}$ 5.692/1971 que, no parágrafo $2^{\circ}$ do Art. 4, manteve e ampliou a ideia de conselhos técnicos e normativos, deu-lhes a incumbência de autorizar e fiscalizar os estabelecimentos estaduais e, assim, abriu espaços para a participação da iniciativa privada nos conselhos de educação, por meio da nomeação de “[...] representantes dos diversos graus de ensino e do magistério oficial e particular, de notório saber e experiência, em matéria de educação [...]". (BRASIL, 1961). O fato é que, para sua sobrevivência, os conselhos aceitaram as circunstâncias dos contextos governamentais e tornaram-se cartoriais, burocráticos e atuaram de acordo com os interesses do governo federal. (SAVIANI, 2006). E, com base nessa concepção, é que o CEE/MS foi criado.

Com a exoneração do primeiro governador de Mato Grosso do Sul, assumiu o governo Marcelo Miranda Soares (1979-1980) e, mesmo representando os interesses de diferentes grupos políticos locais constituídos no Estado, permaneceu apenas dezesseis meses à frente do governo, de 30/06/1979 a 28/10/1980. Assim que assumiu, desmontou a estrutura administrativa organizada pelo seu antecessor e extinguiu a causa principal de 


\section{Revista HIISTEYIDIR On-line}

Artigo

doi: $10.20396 /$ rho.v18i1.8645890

tantas discussões políticas, a SEDRH e todas as suas fundações. As fundações foram substituídas pelas Secretarias de Estado de Educação, Saúde e Desenvolvimento Social.

Com relação ao CEE/MS, no segundo governo, foi assinado o Decreto $\mathrm{n}^{\circ} 255$, de 24 de setembro de 1979, que estabeleceu as regras para a composição e o funcionamento do CEE/MS e incluiu os parágrafos $1^{\circ}, 2^{\circ}, 3^{\circ}, 4^{\circ}$ e $5^{\circ}$, no Art. $2^{\circ}$, do Decreto $n^{\circ} 83 / 1979$, que tratavam da escolha da presidência do colegiado e do ato de posse dos conselheiros, com a seguinte redação:
Art. $2^{\circ}[\ldots]$
$1^{\circ}$ - Na primeira investidura, os Conselheiros tomarão posse perante o Secretário de Estado de Educação;
$2^{\circ}$ - O Presidente e o Vice-Presidente do Conselho serão eleitos dentre seus membros com mandato de 2 (dois) anos, permitida uma recondução imediata;
$3^{\circ}$ - A primeira sessão do Conselho Estadual de Educação, será exercida sob a Presidência do Conselheiro mais idoso presente à sessão que, em seguida, elegerá o Presidente e o Vice-Presidente;
$4^{\circ}$ - E primeira sessão plenária instalar-se-á com a presença de dois terços dos membros do Conselho e passarão a deliberar com a presença da maioria absoluta dos membros do colegiado;
$5^{\circ}$ - Após a assunção do Presidente mais idoso e antes da eleição do Presidente e Vice- Presidente, o plenário delibera sobre os dias das sessões, horário, quórum e votação e outros assuntos que julgar pertinente;
$6^{\circ}$ - Os Conselheiros serão empossados pelo Presidente do Conselho, em sessões do Conselho Estadual de Educação que se realizará na primeira reunião e seguida a nomeação. (MATO GROSSO DO SUL, 1979b).

$\mathrm{Na}$ gestão do terceiro governador do Estado, Pedro Pedrossian (7/11/1980 15/3/1983), do Partido Democrático Social (PDS), mesmo com a existência de um movimento nacional iniciado na década de 1980, organizado pelos setores da sociedade civil e de educadores que solicitavam a criação de espaços públicos e participativos, especialmente no âmbito da gestão educacional e na formulação de políticas públicas, foi publicado somente o Decreto ${ }^{\circ} 1.679$, de 28 de junho de 1982. Esse decreto nada alterou quanto à organização do CEE/MS, apenas regulamentou os pagamentos dos jetons e os cálculos das diárias, para os conselheiros que moravam em cidades do interior e precisavam se deslocar para as reuniões na cidade de Campo Grande, Capital do Estado e sede do Conselho. (MATO GROSSO DO SUL, 1982).

Em 1989, com a promulgação da Constituição Estadual do Estado de Mato Grosso do Sul de 1989 (CE-MS/1989), o CEE/MS teve suas funções ampliadas. No capítulo III - da educação, da cultura e do desporto, no Art. 197, o texto constitucional assegurou a sua existência na estrutura educacional, como "[...] órgão consultivo, deliberativo e normativo da política estadual de educação.” (MATO GROSSO DO SUL, 1989, p. 60).

Embora a CE-MS/1989 tenha prescrito o Conselho com competência de deliberar e normatizar a política estadual de educação, no mesmo Art.197, em seu parágrafo único, faz observância para as condições de seu funcionamento: "[...] a composição, a estrutura 
administrativa, o funcionamento e as atribuições do Conselho Estadual de Educação serão definidos por lei." (MATO GROSSO DO SUL, 1989).

\section{CONSELHO ESTADUAL DE EDUCAÇÃO DE MATO GROSSO DO SUL: 1991 A 1998}

Mesmo com a promulgação da CEE/MS/1989, somente no dia 17 de dezembro de 1993, o governo Pedro Pedrossian (1991-1994) regulamentou o CEE/MS, via Lei Estadual $n^{\circ} 1.460 / 1993$, que, no Art. $2^{\circ}$, fixou competências de interpretar dispositivos da legislação referente ao ensino; propor modificações na organização, funcionamento, expansão e aperfeiçoamento do ensino; aprovar estatutos e regimentos; autorizar experiências pedagógicas; editar normas relativas; promover sindicâncias nas instituições de ensino; aprovar a inclusão de disciplinas nos currículos; dispor sobre seu regimento interno: emitir parecer; manter intercâmbio com o Conselho Federal de Educação e com os demais Conselhos Estaduais de Educação; decidir sobre a autorização para o funcionamento de estabelecimentos de ensino superior, desde que criados e mantidos pelo poder público estadual ou municipal; decidir sobre a autorização e o reconhecimento de cursos nos estabelecimentos de ensino de pré-escolar, $1^{\circ}$ e $2^{\circ}$ graus; e exercer as demais atribuições que lhe forem conferidas pela legislação federal e estadual. Porém todas as ações desse Conselho deveriam ser homologadas pela Secretaria de Educação. (MATO GROSSO DO SUL, 1993).

No tocante à competência deliberativa do CEE, a referida Lei, no Art. $4^{\circ}$, determinou que essa capacidade fosse exercida pelos seguintes órgãos do CEE/MS:

\footnotetext{
I - o Plenário, constituído por todos os seus membros;

II - as Câmaras, que examinarão a s matérias específicas a elas atribuídas, orientando, quando for o caso, as decisões do Plenário.

$\S 1^{\circ}$ A competência do Plenário, bem assim a organização, instalação e competência das Câmaras, serão definidas pelo regimento interno.

$\S 2^{\circ}$ Para o desenvolvimento de suas atividades, o Conselho contará com uma Secretaria Geral. (MATO GROSSO DO SUL, 1993, p. 3).
}

Com relação à competência normativa, por meio da qual um conselheiro deve interpretar a legislação com a devida atenção (CURY, 2006, p. 1), a mesma Lei, no Art. $2^{\circ}$, VII, autorizou o CEE/MS a disciplinar nos seguintes campos de atuação:
a) à organização e ao funcionamento do sistema estadual de ensino;
b) à situação de transferência de discentes dentro ou fora do país;
c) ao tratamento especial a ser dispensado a alunos superdotados e ou portadores de deficiência física ou mental;
d) à fiscalização dos estabelecimentos de ensino não pertencentes à União. (MATO GROSSO DO SUL, 1993, p. 1).

A Lei $n^{\circ} 1.460 / 1993$ também recriou os critérios de representatividade para o procedimento de indicação, ampliou o número de conselheiros para quinze membros 


\section{Revista HIIST'TEIDBR On-line}

efetivos e seis suplentes, escolhidos dentre pessoas de notório saber e experiência em matéria de educação (Art. $3^{\circ}$ ), com mandato de quatro anos com recondução uma única vez $\left(\S 1^{\circ}\right)$; regulamentou o pagamento de jeton e o ressarcimento das despesas de transporte e hospedagem para os conselheiros que residiam em outras localidades que não Campo Grande, capital do Estado ( $\left.§ 7^{\circ}\right)$. (MATO GROSSO DO SUL, 1993).

No exercício da função deliberativa é o conselho "[...] quem aprova, decide, estabelece normas e ações, por meio de resoluções e pareceres." (BORDIGNON, 2009, p. 76). Quando há a interferência direta, ou melhor, quando há a possibilidade de veto do poder executivo nos atos de um conselho de educação, há um estreitamento do espaço democrático e, consequentemente, acontece um retardo no cumprimento dos objetivos da educação brasileira, visto que o Conselho, como órgão participativo e representativo, deve expressar as aspirações da sociedade no seu conjunto.

Em 20 de janeiro de 1994, a Resolução SED/MS n 915/1994 aprovou o Regimento Interno do CEE/MS, manteve o mesmo conteúdo e as mesmas diretrizes da CE/MS (1989), evidentemente, o mesmo número de conselheiros na sua composição, a mesma estrutura e funcionamento. No anexo I, na seção V, no Art. 44, foram incluídos os atos e procedimentos: I- Deliberações; Pareceres; Indicações. Nos artigos 45, 47 e 48, foram explicitados os conceitos de cada ato, conforme exposição a seguir: a) deliberação é um ato normativo de caráter geral, com numeração corrida e data da respectiva aprovação, em plenário. b) parecer é o pronunciamento sobre determinada matéria, com ementa, relatório e análise da matéria e conclusão e voto, submetido à Câmara e Plenário; c) indicação é o ato pelo qual se propõem medidas com vista à expansão e melhoria do ensino. (MATO GROSSO DO SUL, 1994).

No Art. 46, § $1^{\circ}$ da mesma Resolução, foi reafirmada a obrigatoriedade da homologação do Secretário de Educação para que qualquer ato se tornasse oficial, inclusive, com a possibilidade de esses atos serem devolvidos ao Colegiado, para reavaliação e adequação, em atendimento às indicações da SED/MS, conforme demonstra o referido artigo: “[...] o Secretário de Estado de Educação deve homologar ou vetar as deliberações; no todo ou em partes, no prazo de 15 (quinze) dias, contados da data em que lhe foi dado conhecimento oficial." (MATO GROSSO DO SUL, 1994, Art. 46, § 1º). No entanto, como assinala Cury (2006), todos os atos dos conselhos de educação devem ser compatíveis com a Constituição e legislação vigentes e decorrentes delas.

Em 1994, encerrou-se o governo Pedro Pedrossian (1991-1994), que deixou caracterizada a centralidade e o autoritarismo nas suas ações e decisões concentradas no âmbito do Poder Executivo (BIGARELLA, 2004), antagônicas aos princípios estabelecidos na CF/1988. Porém, sincrônicas com ideias do governador, que, após sua eleição (1990), anunciou que iria fazer um programa de descentralização para modernizar o Estado, porém sem abdicar "[...] um milímetro das [suas] prerrogativas." (CORREIO DO ESTADO, 17 jun. 
Artigo

doi: $10.20396 /$ rho.v18i1.8645890

1990 apud BIGARELLA, 2004, p. 83). Coerentes com essa política, a organização e as nomeações dos conselheiros permaneceram com os mesmos critérios criados em 1979.

É importante ressaltar que a nomeação dos conselheiros, conforme demonstra o anexo I da Resolução SED/MS nº 915 de 20 de janeiro de 1994, que aprovou o Regimento Interno do CEE/MS, seguiu os seguintes critérios de escolha: pessoas de notório saber; experiência comprovada na área de educação; indicação política, das instituições privadas e de outras entidades representantes, conforme demonstra o Art. $3^{\circ}$ da Lei 1.460/1993: "o Conselho Estadual de Educação será constituído por quinze membros efetivos e seis suplentes, nomeados pelo Governador do Estado, dentre pessoas de notório saber e experiência em matéria de educação". Continua no $\S 2^{\circ}$, "Na escolha dos membros do Conselho, o Chefe do Poder Executivo levará em conta a necessidade de neles terem devidamente representadas as diversas regiões do Estado, os diversos graus de ensino e o magistério oficial e particular." (MATO GROSSO DO SUL, 1994, p. 2).

Outro ponto importante foi a aprovação do Regimento Interno do CEE/MS, efetivado por meio de resolução da Secretaria de Educação, demonstrando-se que a legislação, desde essa época, restringia o seu caráter deliberativo para resolver as suas próprias demandas institucionais, tais como a aprovação de estatutos e de seus regimentos internos. Ficava assim, o CEE/MS subordinado à homologação para ter validade, o que, na prática, significa falta de autonomia.

É importante observar que a autonomia de um Conselho cria condições administrativas e jurídicas que lhe dão liberdade para tomar decisões, sem se subordinarem a nenhum outro órgão. Isso significa que, embora estejam vinculados às secretarias de educação, não são subordinados a elas. Criados por leis, as quais lhes dão "[...] abertura para o controle jurisdicional de suas decisões." (CURY, 2006, p. 44), possuem regimentos próprios que estabelecem suas funções, atribuições e finalidades.

Na sequência, em 1995, Wilson Barbosa Martins (PMDB - 1995-1998) assumiu o governo do Estado, com a promessa de fazer uma gestão com políticas sociais democráticas, ao mesmo tempo em que faria uma gestão austera e racional dos negócios públicos. Sua proposta estava relacionada às fórmulas expressas no documento Plano Diretor da Reforma do Aparelho de Estado (1995), apresentado no primeiro mandato do governo Fernando Henrique Cardoso (1995-1998), que propôs reforma gerencial, nos moldes da Reforma do Estado. (BRASIL, 1995).

Conforme Mensagem à Assembleia Legislativa de Mato Grosso do Sul n n 012, de 15 de fevereiro de 1996, tal reforma buscava substituir o modelo de administração pública burocrática/clientelista/patrimonialista, por uma administração pública gerencial, que adotaria outros princípios de organização pública: o fortalecimento do setor privado, buscando limitar a interferência supletiva ou direta do Estado na atividade econômica; a descentralização das atividades administrativas e executivas do governo; a desconcentração 
espacial de suas ações, delegando a execução de projetos e atividades a setores privados predominando seu interesse nos setores sociais, priorizando os mais vulneráveis. (MATO GROSSO DO SUL, 1996).

Em acerto com as diretrizes da agenda da reforma administrativa, que tinham como prioridade desenvolver uma gestão austera, racional, autônoma e descentralizada, para promover a redução dos gastos com a área social, a Secretaria de Educação direcionou as políticas de gestão educacional para três eixos: "[...] a igualdade de oportunidades, a premiação por mérito, a imparcialidade, a eficiência e a eficácia na aplicação dos recursos." (MATO GROSSO DO SUL, 1996, p. 8). Todavia tal intenção não se transformou em prática social nem em políticas mais democráticas para a área educacional, tampouco refletiu no aumento de autonomia do CEE/MS, ao contrário, somente aumentou a sua dependência nas decisões do Executivo.

Nesse período, foi aprovada pelo Congresso Nacional e homologada pelo presidente da República a Lei de Diretrizes e Bases da Educação Nacional (LDB), Lei no 9.394/1996 (BRASIL, 1996). Em decorrência, o CEE/MS, como órgão normativo do Sistema Educacional, respaldado pela CE de MS/1989 (MATO GROSSO DO SUL, 1989) e legislação produzida desde sua criação, implementou a elaboração de normas, com vistas a atender aos dispositivos legais, naquilo que exigia regulamentação em âmbito estadual. De 1997 a 1998, nos dois primeiros anos de vigência da referida Lei, esse Conselho, no exercício de funções que definem a sua natureza e seu papel na gestão educacional, produziu, além das resoluções referentes a suas competências, seis pareceres orientativos que estabeleceram normas complementares, com vistas à regulamentação de dispositivos para serem implementados na legislação educacional sul-mato-grossense. (MATO GROSSO DO SUL, CEE/MS, 1997).

No entanto o Conselho não definiu os elementos constitutivos para orientar, por exemplo, o processo de construção da gestão democrática do ensino público, em indicação ou deliberação publicadas desde a promulgação da Lei 9.394/1996 até 1998, período de regulamentação e adaptação da lei aos sistemas de ensino. O foco do Conselho foi na regulamentação dos currículos, sobre estudos de recuperação, na carga horária mínima anual e dias de efetivo trabalho escolar, nas normas para autorização de funcionamento das Instituições de Ensino Superior, na organização das instituições escolares.

Conforme demonstraram os pareceres orientativos, o Conselho não faz referências aos pontos básicos de ações, que materializam a gestão democrática: o processo de participação coletiva (segmentos da comunidade escolar e local), a representatividade das instâncias colegiadas com funções deliberativas, o processo de escolha de dirigentes escolares, a autonomia escolar, a participação da comunidade na definição da aplicação dos recursos recebidos pelas unidades escolares. Nesse sentido, não ficaram explicitados os 
critérios de como organizar um ambiente favorável que instigasse a participação coletiva dos envolvidos no processo educacional. (MATO GROSSO DO SUL, 2014a).

Esse Conselho, como tem a função de decidir sobre matérias específicas quando normatiza, ao não explicitar diretrizes gerais para a construção de instrumentos de gestão democrática, não regulamentou o seu funcionamento no Sistema de Ensino de Mato Grosso do Sul, não ampliou o ordenamento constitucional, nem da Lei de Diretrizes e Bases da Educação Nacional, por consequência, não favoreceu esse processo de construção de gestão democrática nesse período, apesar de o Parecer CEE/MS nº 223/1997 ter registrado que:

\footnotetext{
Esse Colegiado, frente à responsabilidade de nortear as ações das instituições de ensino, em MS, realizou o I Seminário Estadual da LDB, de 28 a 30/04/97, em Campo Grande, em parceria com UFMS, UEMS, UNIDERP, UCDB, FETEMS, SINEPE/MS, DEMEC/MS, SINTRAE/MS, SED/MS, SEMED/CG, OMEP/BR/MS, UNDIME/MS, para o qual convocou professores, técnicos, especialistas, pesquisadores na área de Educação e sindicalistas, com objetivo de propiciar a estes participantes a reflexão inicial sobre os principais temas da LDB (Educação Básica, Educação Superior, Educação de Jovens e Adultos, Educação Profissional e Educação Especial). (MATO GROSSO DO SUL, 1997, p. 1).
}

A gestão democrática implica um processo de participação coletiva. Para que se efetive em um sistema educacional, é necessária uma mudança de paradigma. Para isso, a participação precisa deixar de ter uma postura restrita e funcional, de controle dos processos administrativos, para se transformar em mecanismos efetivos de democratização e em uma "[...] nova cultura do cotidiano escolar, como expressão de um projeto coletivo envolvendo a comunidade local e escolar." (DOURADO, 2006, p. 49).

Mesmo não sendo uma área de "democracia absoluta", os conselhos de educação configuram-se como espaços de ação, de participação da sociedade civil na constituição do poder político. Nesse sentido, "podem ou não" contribuir para o fortalecimento da democratização da educação no âmbito dos sistemas de ensino. Sua maior ou menor contribuição dependerá das suas funções, dos seus fundamentos, ordenamento legal, composição e representatividade. (CURY, 2001, 2006, 2011).

Uma vez discutida a regulamentação desse Conselho, nesse período até a aprovação da LDB, Lei no 9.394 de 1996, será abordada na próxima seção, sua regulamentação no período correspondente aos dois mandatos do governo José Orcírio Miranda dos Santos.

\section{CONSELHO ESTADUAL DE EDUCAÇÃO DE MATO GROSSO DO SUL: 1999 A 2014}

Em 1999, o Partido dos Trabalhadores assumiu pela primeira vez o governo do Estado de Mato Grosso do Sul, com a eleição de José Orcírio Miranda dos Santos, conhecido como Zeca do PT (1999-2002). Esse governo definiu cinco macros objetivos que deveriam 
Artigo

doi: $10.20396 /$ rho.v18i1.8645890

nortear todos os programas, projetos e ações do governo: combate à pobreza e à exclusão social; retomada do desenvolvimento; conservação do meio ambiente; fortalecimento da gestão pública e efetiva participação popular. No seu plano de desenvolvimento, segundo a Mensagem à Assembleia Legislativa, focou na ampliação dos níveis de desenvolvimento social, na oferta de emprego e renda e na melhoria da qualidade de vida da população. (MATO GROSSO DO SUL, 2000b).

O projeto político do governo José Orcírio Miranda dos Santos (1999-2002), pretendia a "[...] construção de um processo sustentável de desenvolvimento para o Estado de Mato Grosso do Sul, que [contemplasse] a valorização humana e sua efetiva participação no processo de gestão e definição da aplicação dos recursos públicos." (MATO GROSSO DO SUL, 2000b, p. 4). Para tanto, estabeleceu prioridades e linhas econômicas de distribuição para atender à população em decorrência do desenvolvimento local e regional, mediante a criação dos seguintes programas: Programa de Desenvolvimento da Produção Agropecuária (PDAgro), no âmbito da Secretaria da Produção e Desenvolvimento Sustentável, o Fundo de Desenvolvimento do Sistema Rodoviário de Mato Grosso do Sul (FUNDERSUL), o Banco do Povo, o Bolsa Escola, Saúde da Família e, no âmbito do Planejamento, o Orçamento Participativo, os Cenários para Mato Grosso do Sul e o Plano de Desenvolvimento - MS 2020. (MATO GROSSO DO SUL, 2000b).

Nos anos de 1999 a 2002, as políticas sociais de educação, de saúde e para a agricultura familiar ganharam prioridade nos investimentos do Estado. O Governo planejou políticas públicas que ofereciam créditos assistidos, assistência técnica e de gerenciamento e formação de pequenas empresas. Deu continuidade à proposta de uma ampla reforma administrativa do Poder Executivo, mas com algumas diferenças. Reduziu de dezenove secretarias e subsecretarias, para dez, retirou o subsídio do programa de desestatização com a modernização e privatização da Empresa Energética de Mato Grosso do Sul (ENERSUL) e deu mais atenção à política social e ao papel do Estado no desenvolvimento local, tanto econômico, quanto social. Mas, no segundo mandato (2003-2006), o foco do governo mudou para um modelo de desenvolvimento assentado sobre o crescimento econômico. (MATO GROSSO DO SUL, 2000b).

Nesse contexto, paralelo às políticas governamentais, prevista na Lei 2.152, de $26 \mathrm{de}$ outubro 2000, foi desenvolvida a "[...] reorganização da estrutura básica do Poder Executivo do Estado de Mato Grosso do Sul" (MATO GROSSO DO SUL, 2000a, p.1), buscando reduzir o tamanho da administração pública. Essa reorganização foi coordenada por Gleisi Helena Hoffmann (PT), Secretária de Estado de Reestruturação e Ajuste, com a assessoria do professor da UFMS Dario Lima Filho, para instituir, na administração estatal, "[...] as finalidades do plano de governo, eficiência da administração e equilíbrio fiscal." (LIMA FILHO; HOFFMANN, 2002, p. 3). 


\section{Revista HIIST'TEIDBR On-line}

Artigo

doi: $10.20396 /$ rho.v18i1.8645890

Segundo os coordenadores da proposta, Lima Filho e Hoffmann (2002, p. 3), a intenção era "[...] torná-la instrumento de mudanças políticas, econômicas e sociais" e sanar o endividamento que vinha se arrastando desde a criação do Estado (1979), especialmente, com deferência aos recursos destinados ao pagamento dos funcionários públicos, os quais naquele momento estavam correndo o risco de não serem pagos. Essas despesas, historicamente, vinham sendo '[...] cobertas ou com 'imposto inflacionário' ou com empréstimos de curto prazo (a juros elevados)" (LIMA FILHO; HOFFMANN, 2002, p. 3).

No segundo mandato do governo José Orcírio Miranda dos Santos (PT -2003-2006), na gestão do Secretário de Educação Hélio de Lima (PT -2003-2006), por ocasião da discussão da proposta do Plano Estadual de Educação de Mato Grosso do Sul (PEE/MS2003), foi aprovada a Lei no $2.787 / 2003$, que dispõe sobre o Sistema Estadual de Ensino de Mato Grosso do Sul. (MATO GROSSO DO SUL, 2004).

A Lei reafirmou na seção V, no Art. 26, o Conselho como órgão colegiado de caráter normativo, consultivo, deliberativo e lhe atribuiu outra função: assessoramento superior da Secretaria de Estado de Educação, e com representação paritária entre o Governo do Estado e entidades da sociedade civil organizada. Todavia, no Art. 28, ao fixar as suas funções e atribuições, reduziu sua autonomia, diminuiu o número de suas competências (de dezoito para dez) em relação ao que estava expresso na Lei Estadual no 1.460/1993. Assim, conforme a Lei n ${ }^{\circ}$.787/2003, coube ao Conselho Estadual de Educação, conforme art. 28, as seguintes atribuições:

\footnotetext{
I - Participar da elaboração da política educacional do Estado;

II - Acompanhar a execução da política educacional;

III - participar da elaboração de políticas públicas nas áreas de educação básica e educação superior, conjuntamente com órgãos públicos e particulares que atuam nessas áreas ou que possuem ações específicas nas áreas de educação infantil indígena, educação especial, educação de jovens e adultos, formação profissional e tecnológica;

IV - Avaliar e fiscalizar a execução das políticas públicas nas áreas mencionadas no inciso anterior;

V - Normatizar e emitir parecer sobre questões relativas à aplicação da legislação educacional no âmbito do Sistema Estadual de Ensino;

VI - Fiscalizar o cumprimento da legislação educacional no Estado;

VII - Emitir parecer sobre assuntos e questões de natureza educacional que lhes forem submetidos pelos Poderes Executivo e Legislativo e de outras instituições; VIII - emitir parecer sobre assuntos da área educacional, por iniciativa de seus conselheiros ou de quando solicitado pelo Secretário de Estado de Educação;

IX - Exercer as demais atribuições que a legislação federal confere aos Conselhos Estaduais de Educação, assim como, no que couber no âmbito estadual às questões consignadas pelo Conselho Nacional de Educação, em relação ao Sistema Federal de Ensino;

$\mathrm{X}$-Elaborar e alterar o seu regimento a ser homologado pelo Secretário de Estado de Educação. (MATO GROSSO DO SUL, 2003, p. 15).
}

Essas atribuições definiram o Conselho como um órgão que participa da elaboração e acompanha a execução da política educacional, assim como habilita, credencia, reconhece 
e autoriza cursos, valida estudos, fixa normas de funcionamento das escolas entre outras tarefas de caráter mais burocrático. No Art. 31, foi confirmado que os “[...] atos emanados do Conselho Estadual de Educação adquirem eficácia após sua homologação pelo Secretário de Estado de Educação, e publicação no Diário Oficial do Estado." (MATO GROSSO DO SUL, 2003, p. 10). Assim, as decisões tomadas no âmbito dos conselhos, para produzir efeito prático e serem colocadas em execução, fossem homologadas pelo Poder Executivo, nesse caso, o Secretário de Estado de Educação.

Essas homologações, portanto, podem ser vistas como ato de resistência do governo quanto à tomada de decisões do Conselho, desconsiderando-o como cogestor da política educacional, ou mesmo podem obstruir as suas ações. Essas questões estão relacionadas à autonomia imprescindível a qualquer colegiado, que precisa de liberdade para concretizar o seu papel de controle social sobre as ações do governo. Sem colaboração dos governos, não há possibilidade de um conselho constituir-se como elo entre Estado e sociedade. (CURY, 2006).

A forma de escolha dos conselheiros titulares se fez presente pela Lei 2.787/2003 e remontou à obediência ao critério do notório saber anunciado no Decreto-Lei no 8/1979 e na Lei $n^{\circ}$ 1.460/1993. A lei indicou como seria a composição do Conselho Estadual de Educação de Mato Grosso do Sul, da seguinte forma:

O art. 29. O Conselho Estadual de Educação de Mato Grosso do Sul será integrado por 15 (quinze) conselheiros titulares, escolhidos entre pessoas de notório saber e experiência em matéria de educação, nomeados pelo Governador do Estado, consoante o disposto nesta Lei, para exercer um mandato de quatro anos. (MATO GROSSO DO SUL, 2003, p. 15).

Com esse parágrafo, continuou fluindo o entendimento presente na LDB $\mathrm{n}^{\circ}$ 4.024/1961, de que os conselheiros deveriam ser intelectuais, com muita sabedoria. Porém essa ideia é incompatível com a Constituição de 1988 e com a LDB 9.394/1996. Estas trazem uma concepção baseada na participação ativa do cidadão, tem a gestão democrática como princípio, requer outros valores e espaços de participação da sociedade. Após a Constituição e a abertura democrática no país, os conselhos de educação exigem pluralismo representativo, para exercer papel decisório nas políticas públicas educacionais. Assim, nesse novo contexto, a composição dos conselhos exige não mais unicamente o saber acadêmico, mas a demonstração dos vários e diversos saberes sociais. A composição expressa a representatividade e a correlação de forças de um Conselho. (PERONI, 2008).

$\mathrm{O}$ art. 30 da Lei $\mathrm{n}^{\circ}$ 2.787/2003 indicou a composição dos 15 membros do CEE/MS e observa a seguinte proporção:

I - Conselheiros Titulares:

a) 2 (dois) representantes indicados pelo Governador;

b) 4 (quatro) representantes da Secretaria de Estado de Educação;

c) 1 (um) representante da Universidade Estadual de Mato Grosso do Sul - UEMS; 


\section{Revista HIIST'TEIDBR On-line}

ISSN: 1676-2584

Artigo

doi: $10.20396 /$ rho.v18i1.8645890

d) 1 (um) representante da Universidade Federal de Mato Grosso do

Sul - UFMS;

e) 1 (um) representante das Instituições Superiores Privadas de Ensino;

f) 1 (um) representante da Federação dos Trabalhadores em Educação Pública do Estado de Mato Grosso do Sul - FETEMS;

g) 1 (um) representante da União dos Dirigentes Municipais de Educação UNDIME;

h) 1 (um) representante da Federação Interestadual de trabalhadores em Estabelecimento de Ensino - FITRAE/MS

i) 1 (um) representante do Sindicato das Escolas Particulares de Mato Grosso do Sul - SINEPE/MS;

j) 1 (um) representante da Federação Empresarial de Mato Grosso do Sul;

k) 1 (um) representante dos movimentos populares que realizem atividades ou experiências na área educacional. (MATO GROSSO DO SUL, 2003, p. 15-16).

Essa composição, apesar de manter um representante da União Nacional dos Dirigentes Municipais de Educação (UNDIME), um representante da Federação dos Trabalhadores em Educação Pública do Estado de Mato Grosso do Sul (FETEMS) e um dos movimentos populares, conservou a representação dos mesmos interesses históricos presentes nos períodos e governos anteriores. O predomínio de representantes do poder público, somado ao critério de escolha pelo notório saber, revela tendências a ações burocráticas, nas quais prepondera o controle do Executivo e que conflitam com as exigências do processo de construção democrática, pois intercorrem, por exemplo, na ausência de representantes da escola: pais, alunos e professores das redes pública e privada, bem como alunos, pais e professores, indígenas, negros, quilombolas, comunidades rurais e outros grupos que, de modo geral, não são ouvidos nos momentos de decisões. Isso suscita questionamentos sobre o pluralismo representativo do Conselho de Educação, na medida em que, na sua composição, não há representatividade de todos os grupos usuários das escolas.

Importa observar que a paridade sociedade-governo nos conselhos de educação, no entendimento de Cury $(2006,2011)$, é uma condição sine qua non para que se crie um espaço para o debate real entre diferentes posições e interesses. A igualdade numérica de participantes do Estado e da sociedade é uma exigência para tomar decisões mutuamente aceitáveis e para dar um formato democrático às políticas educacionais.

Nesse sentido, assinala o autor, são esses critérios que o tornam órgão de Estado. E nesse exercício assegura-se "[...] a participação da sociedade no aperfeiçoamento da educação nacional [...], os princípios legais estabelecidos pela CF/1988 e LDB 9.394/1996 [...], a garantia da educação como direito de todos os cidadãos e dever do Estado." (CURY, 2001, p. 50). Assim, acrescenta o autor, a participação dos conselhos na elaboração das políticas é fundamental para que elas se concretizem. O Conselho deve "[...] ser considerado um parceiro nas grandes definições de uma deliberação ou de um ordenamento." (CURY, 2001, p. 50), pois, ainda de acordo com o autor é aqui que está o papel do Conselho, no aprimoramento do controle social e do pluralismo político, na participação, na representatividade social e na democratização do Estado. 
Um ponto positivo na composição do Conselho Estadual de Educação são as vagas para os representantes da Federação dos Trabalhadores em Educação Pública do Estado de Mato Grosso do Sul e da Federação Interestadual de Trabalhadores em Estabelecimento de Ensino Privado e um representante dos movimentos populares que realizem atividades ou experiências na área educacional, mas ainda falta dar espaços para representantes da comunidade escolar.

Na verdade, seus atos dependem de homologação do Executivo, para terem validade, conforme evidencia o "Art. 20, ou seja, ao Presidente do Conselho incumbe: [...] XIV encaminhar as deliberações do Conselho ao Secretário de Estado de Educação, para homologação." (MATO GROSSO DO SUL, 2005, p. 6).

A Secretaria de Estado de Educação (2003 a 2006), mediante a Resolução/SED n ${ }^{\circ}$ 1.848/2005, reconheceu a necessidade da participação do Conselho na elaboração, acompanhamento do Plano Estadual de Educação, quando elenca as suas atribuições no art. $7^{\circ}$ - São atribuições da Câmara de Educação Básica:

I - Participar da elaboração, acompanhamento e implementação de políticas e planos educacionais, relativos à educação básica, em consonância com as normas legais vigentes;

II - Propor normas orientativas para a organização, a estrutura e o funcionamento da educação básica nas unidades escolares pertencentes ao Sistema Estadual de Ensino, em atendimento às normas propostas pelo Conselho Nacional de Educação encaminhando à Plenária para apreciação;

III - propor indicação para alteração de normas educacionais inerentes ao

Sistema Estadual de Ensino;

IV - Oferecer sugestões para a elaboração e acompanhamento do Plano

Estadual de Educação, com observância das disposições legais;

$\mathrm{V}$ - Analisar questões concernentes à aplicação da legislação relativa à educação básica;

VI - Emitir parecer sobre as questões inerentes à educação básica;

VII - emitir parecer sobre assuntos e questões de natureza pedagógica e educacional que lhe sejam submetidos pelo Presidente do Conselho Estadual de Educação;

VIII - propor a realização de audiências públicas para discussão prévia de normas a serem editadas pelo Conselho Estadual de Educação;

IX - Aprovar as deliberações concessivas e de indeferimento;

$\mathrm{X}$ - Propor à Plenária, a instauração de sindicâncias e ou processo administrativo em unidade escolar pertencente ao Sistema Estadual de Ensino;

XI - manter intercâmbio com os Sistemas de Ensino dos municípios;

XII - desempenhar outras tarefas que lhe forem atribuídas pelo presidente do Conselho Estadual de Educação;

XIII - propor pauta de reuniões. (MATO GROSSO DO SUL. 2005, p. 3).

No desempenho de suas atribuições, a Resolução/SED no 1.848/2005 inseriu uma função mais propositiva, ao recomendar o seu acompanhamento no Plano Estadual de Educação, e outra fiscalizadora, ao indicar como uma de suas tarefas o recredenciamento das instituições de educação superior, suspensão do funcionamento de cursos e a instauração de sindicâncias. Essa última função está intrinsecamente relacionada à sua função normativa, 
uma vez que alude ao cumprimento dos seus atos normativos e da legislação vigente. (MATO GROSSO DO SUL, 2005). Assim, o Conselho Estadual de Mato Grosso do Sul, no período de 1999 a 2006, constituiu-se mais como órgão normativo da gestão educacional, com orientações mais voltadas para o estabelecimento de normas e fiscalização das instituições educacionais da Rede Estadual de Ensino.

Na gestão seguinte, André Puccinelli, do Partido do Movimento Democrático Brasileiro (PMDB), foi eleito para o primeiro mandato como governador (2007 - 2010) e reeleito para um novo mandato (2011-2014), sendo a quarta vez que um representante do PMDB assumiu a administração de Mato Grosso do Sul. Apenas no período de 1991-1994, durante o governo Pedro Pedrossian, do PTB, e de 1999 a 2006, no governo José Orcírio Miranda dos Santos, do PT, é que o PMDB não esteve à frente da administração do Estado. Convém observar que o período dessa administração coincide, em âmbito nacional, com o segundo mandato do governo Luiz Inácio Lula da Silva (2007-2010).

Nesse governo (2007-2014), o gerenciamento na gestão pública passou a ser uma questão de primeira ordem. A modernização gerencial da educação entrou para a agenda do governo como proposta política associada à necessidade de controlar os recursos financeiros da unidade escolar, como estratégia para ofertar uma educação de qualidade. Assim, buscava trazer para a educação a máxima da eficácia das empresas privadas: fazer mais com menos recursos. Essa proposta não dependia somente do controle financeiro e da redução de gastos, dependia muito da intervenção da Secretaria de Educação com uma estratégia gerencial que fosse orientada pelos parâmetros de eficiência, eficácia e efetividade e da responsabilização do diretor escolar pela tarefa de "[...] gerenciar o planejamento, a execução e a avaliação das atividades administrativa, financeira e pedagógica da escola." (MATO GROSSO DO SUL, 2008, p. 2).

Nesse quadro institucional hierárquico e vertical, restaram poucos espaços na gestão educacional para a atuação de agentes democráticos, uma vez que esse modelo centralizou as decisões no âmbito da Secretaria de Estado de Educação, limitando as discussões políticas e ampliando espaços para as ações técnicas e normativas. Do ponto de vista da gestão eficaz, a escolha, a elaboração, o acompanhamento e a execução de planos, programas e projetos concentrados no órgão central são percebidos como estratégia para obter: "[...] melhores resultados nas avaliações internas e externas, garantir a educação de qualidade para os alunos e valorizar o professor como um profissional que tem a missão de transmitir o conhecimento aos educandos." (MATO GROSSO DO Sul, 2013, p. 132). Esses limites demarcaram os contornos do papel do Conselho Estadual de Educação de Mato Grosso do Sul no período (2007-2014).

Embora com concepção diferente de gestão do governo anterior, conforme demonstra a Resolução/SED n n 2.848/2014, o seu papel histórico normativo/credencialista e 
a sua composição de 15 membros não se alteraram, conforme demonstram os fragmentos de texto do Regimento Interno do Conselho (2014):

\begin{abstract}
Art. $2^{\circ} \mathrm{O}$ CEE/MS é composto por quinze conselheiros titulares e igual número de conselheiros suplentes, nomeados pelo Governador do Estado, para mandato de quatro anos, atendendo à representatividade prevista em lei.

[...]

Art. 10. O Conselho Pleno, além das funções atribuídas às Câmaras, tem competência para elaborar e aprovar normas para o Sistema Estadual de Ensino. (MATO GROSSO DO SUL, 2014b, p. 1-2).
\end{abstract}

$\mathrm{Na}$ dinâmica de funcionamento do Conselho, as suas competências estão relacionadas ao atendimento das demandas do Sistema Estadual de Ensino, especialmente, aos atos que introduzem ou disciplinam os procedimentos e mecanismos de ordem administrativa: autorizações, funcionamento e reconhecimentos de estabelecimentos da educação básica. Assim determina o Regimento Interno do Conselho (2014).

Esses dados indicam que esse Conselho tem entraves que ainda não lhe permitem desempenhar, de maneira efetiva, o seu papel de fórum articulador. Esse governo (20072014) manteve a ausência de representantes da comunidade escolar. Esses dispositivos demonstram que esse Colegiado ainda mantém interesses elitistas que dificultam a ampliação da gestão democrática na área educacional sul-mato-grossense. Reforça também o protagonismo do Executivo na definição das políticas públicas.

\title{
CONSIDERAÇÕES FINAIS
}

O Conselho Estadual de Educação de Mato Grosso do Sul (CEE/MS), foi criado em 1979, em consonância com a ordem político-institucional do regime civil-militar (19641985), sob a égide da Lei 5.692/1971, recebeu basicamente atribuições fiscalizadoras, de natureza econômico-financeira, encargo, até então, atribuído à Superintendência Nacional de Abastecimento (SUNAB), e foi composto por representantes dos diversos graus de ensino e do magistério oficial e particular, de notório saber e experiência, em matéria de educação.

A trajetória desse Conselho mostra que, desde a sua gênese, sua composição foi pouco plural, levando-o a assumir a conformação de órgão de governo, uma vez que se mostrou ausente na tomada de decisões a respeito das políticas educacionais. Somente em 1993, em decorrência da Constituição Estadual de Mato Grosso do Sul, de 1989, regulamentado pela Lei Estadual $n^{\circ} 1.460 / 1993$, foram fixadas as suas competências, organização, normas de funcionamento e suas funções: consultiva, deliberativa e normativa da política de educação.

Mesmo com as três funções garantidas por lei, assumiu-se como órgão normativo, que foram dedicadas a tarefas de natureza operacional para a Secretaria de Estado de Educação: à instauração de sindicâncias e verificação de processos administrativos em 
unidades escolares pertencentes ao Sistema Estadual de Ensino (autorizações, equivalências, credenciamentos).

Esse posicionamento ressaltou o seu caráter consultivo na função de assessoramento das ações do governo na área de educação, avocado para colaborar, expressar e legitimar a vontade de governo. No período (2010-2014), delegou competências para a da Secretária Estadual de Educação para credenciar, aprovar projetos e autorizar o funcionamento de cursos na modalidade presencial e educação a distância.

Essa disposição foi sendo reforçada ao longo do tempo pela ausência de pluralidade na sua representatividade e pela falta de revezamento de conselheiros, que permaneceram na composição do Conselho por mais de 20 anos, como representantes do aparelho governamental, ora como titulares, ora como suplentes, contribuindo assim para a sua acomodação e distanciamento das questões educacionais.

\section{REFERÊNCIAS}

ABRUCIO, F. L. O impacto do modelo gerencial na administração pública: um breve estudo sobre a experiência internacional recente. Brasília: ENAP, 1997.

BASTOS, C. R. (Ed.). Curso de direito constitucional. São Paulo, 2002.

BIGARELLA, N. Materialização da política de municipalização do ensino fundamental de Mato Grosso do Sul nos anos 1993 a 2002. Dissertação (Mestrado em Educação) Universidade Federal de Mato Grosso do Sul, Campo Grande, MS, 2004.

BORDIGNON, G. Gestão da educação no município: sistema, conselho e plano. São Paulo: Instituto Paulo Freire, 2009.

BRASIL. Constituição (1967). Brasília, 24 jan. 1967. Diário Oficial [da] República Federativa do Brasil, Brasília, 24 jan. 1967a.

BRASIL. Constituição (1988). Brasília, DF: Senado Federal, 1988.

BRASIL. Decreto-Lei n ${ }^{\circ}$ 200, de 25 de dezembro de 1967. Dispõe sobre a organização da Administração Federal, estabelece diretrizes para a Reforma Administrativa e dá outras providências. Diário Oficial [da] República Federativa do Brasil, Brasília, 27 mar. 1967b. Suplemento. Disponível em: <http://www.planalto.gov.br/ccivil_03/DecretoLei/Del0200.htm>. Acesso em: 12 nov. 2013.

BRASIL. Decreto-Lei no 532, de 17 de abril de 1969. Presidência da República: Arthur da Costa e Silva. Dispõe sobre a fixação e o reajustamento de anuidades, taxas e demais contribuições do serviço educacional. Brasília, 1969.

BRASIL. II Plano Nacional de Desenvolvimento (1975-1979). Brasília, 1974. 
Artigo

doi: $10.20396 /$ rho.v18i1.8645890

BRASIL. Lei n. 4.024, de 20 de dezembro de 1961. Fixa as Diretrizes e Bases da Educação Nacional. Brasília: Congresso Nacional, 1961.

BRASIL. Lei n. 5.692/71, de 11 de agosto de 1971. Fixa as Diretrizes e Bases para o ensino de primeiro e segundo grau e dá outras providências. Brasília, 11 ago. 1971.

BRASIL. Lei n. 9.394, de 20 de dezembro de 1996. Estabelece as Diretrizes e Bases da Educação Nacional. Diário Oficial [da] República Federativa do Brasil, Brasília, n. 248, ano CXXXIV, 23 dez. 1996.

BRASIL. Lei Complementar $n^{\circ}$ 31, de 11 de outubro de 1977. Cria o Estado de Mato Grosso do Sul, e dá outras providências. Brasília, 11 de outubro de 1977. DOU de 12.10.1977.156º da Independência e 89 da República, Presidente Ernesto Geisel. Brasília, 1977.

BRASIL. Ministério da Administração Federal e Reforma do Estado. Plano Diretor da Reforma do Aparelho do Estado. Brasília, 1995.

COSTA, H. A. Discurso de Harry Amorim Costa no ato de instalação do Estado de Mato Grosso do Sul. Jornal Correio do Estado, Campo Grande, MS, 3 jan. 1979a.

COSTA, H. A. Discurso de posse: governador Harry Amorim Costa, à Assembleia Constituinte de Mato Grosso do Sul. Campo Grande, MS, 1. jan. 1979 b.

CURY, C. R. J. Conselho de Educação: fundamentos e funções. Revista Brasileira de

Política e Administração da Educação: RBPAE, v. 22, n. 1, p. 1-184, jan./jul. 2006.

CURY, C. R. J. Consulta sobre o entendimento e o alcance das expressões "Órgão responsável pela Educação e Órgãos responsáveis pelos Sistemas de Ensino". Processo n. 23001.000385/2000-17, Parecer: 04/2001, CEB, 30/01/2001. Despacho do Ministro em 22/2/2001. Diário Oficial [da] República Federativa do Brasil, Brasília, 23 fev. 2001. Seção 1, p. 27.

CURY, C. R. J. Os conselhos de educação e a gestão dos sistemas. In: FERREIRA. N. S.; AGUIAR, M. da S. (Org.). Gestão da educação: impasses, perspectivas e compromissos. 4. ed. São Paulo: Cortez, 2011.

DOURADO, L. F. Gestão da educação escolar: Ministério da Educação: Secretaria de Educação Básica. Brasília: Ed. da UnB, Centro de Educação a Distância, 2006.

FERNANDES, M. D. E. Políticas públicas de educação: a gestão democrática na rede estadual de ensino em Mato Grosso do Sul (1991 a 1994). 1996. Dissertação (Mestrado em Educação) - Universidade de Mato Grosso do Sul, Mato Grosso do Sul, 1996.

HERMANN, J. Auge e declínio do modelo de crescimento com endividamento: o II PND e a crise da dívida externa (1974-1984). In: GIAMBIAGI, F. et al. (Org.). Economia

brasileira contemporânea. Rio de Janeiro: Elsevier, 2005. p. 93-115. 
IANNI, O. Ditadura e agricultura: o desenvolvimento do capitalismo na Amazônia, 19641978. 2. ed. Rio de Janeiro: Civilização Brasileira, 1986.

LIMA FILHO, D. de.; HOFFMANN, G. H. Reforma administrativa e as resistências externas: o caso de Mato Grosso do Sul. Revista ENANPAD, n. 26, 2002.

MATO GROSSO DO SUL (Estado). Conselho Estadual de Educação. Atos normativos. Campo Grande, MS, 2014. Disponível em: 〈http://www.cee.ms.gov.br〉. Acesso em: 21 mar. 2014a.

MATO GROSSO DO SUL (Estado). Conselho Estadual Parecer Orientativo CEE/MS n ${ }^{\circ}$ 223/1997. Orientações Preliminares do Conselho Estadual de Educação/MS sobre a Lei ${ }^{\circ}$ 9.394/96. Campo Grande, MS, 20 de agosto de 1997.

MATO GROSSO DO SUL (Estado). Constituição 1989. Constituição do Estado de Mato Grosso do Sul de 1989. Campo Grande, MS: Assembleia Legislativa, 1989.

MATO GROSSO DO SUL (Estado). Decreto no 83, de 14 de março, de 1979. Dispõe sobre a composição e o funcionamento do Conselho Estadual de Educação e dá outras providências. Campo Grande, MS, mar. 1979a.

MATO GROSSO DO SUL (Estado). Decreto $\mathrm{n}^{\circ}$. 255, de 24 de setembro de 1979. Inclui dispositivos no Decreto no 83 de 14 de março de 1979 que, dispõe sobre a composição e o funcionamento do Conselho Estadual de Educação e das outras providências. Campo Grande, 24 de setembro de 1979b.

MATO GROSSO DO SUL (Estado). Decreto $n^{\circ} 1.679$, de 28 de junho de 1982. Altera a organização do CEE/MS e regulamenta os pagamentos dos jetons e os cálculos das diárias. Governo Pedro Pedrossian, Campo Grande, 1982.

MATO GROSSO DO SUL (Estado). Decreto-Lei no 1 , de $1^{\circ}$ de janeiro de 1979. Estabelece a organização básica do Estado de Mato Grosso do Sul e dá outras providências. Campo Grande, MS, 1979c.

MATO GROSSO DO SUL (Estado). Decreto-Lei $n^{\circ}$ 2, de $1^{\circ}$ de janeiro de 1979. Dispõe sobre a organização da Administração Pública do Poder Executivo do Estado de Mato Grosso do Sul e dá outras providências. Campo Grande, MS, 1979d.

MATO GROSSO DO SUL (Estado). Decreto-Lei ${ }^{\circ}$ 8, de $1^{\circ}$ de janeiro de 1979. Dispõe sobre o Sistema Executivo para o Desenvolvimento de Recursos Humanos, autoriza a criação das entidades que menciona e dá outras providências. Campo Grande, MS, 1979e.

MATO GROSSO DO SUL (Estado). Lei nº 1.460, de 17 de dezembro de 1993. Dispõe sobre o Conselho Estadual de Educação - CEE/MS, e dá outras providências. Campo Grande, 1993. 
MATO GROSSO DO SUL (Estado). Lei n ${ }^{\circ}$ 2.152, de 26 de outubro de 2000. Dispõe sobre a reorganização da estrutura básica do Poder Executivo do Estado de Mato Grosso do Sul e dá outras providências. Campo Grande, 26 out. 2000a.

MATO GROSSO DO SUL (Estado). Lei no 2.787, de 2003, de 24 de dezembro de 2003. Dispõe sobre o Sistema Estadual de Ensino de Mato Grosso do Sul e dá outras providências. Campo Grande: Secretaria de Estado de Educação de Mato Grosso do Sul, 2003.

MATO GROSSO DO SUL (Estado). Mensagem à Assembleia Legislativa, $\mathrm{n}^{\circ}$ 012, de 15 de fevereiro de 1996. Balanço e perspectivas: governador Wilson Barbosa Martins. Campo Grande, MS, 1996.

MATO GROSSO DO SUL Mensagem à Assembleia Legislativa n. 10, de 4 de fevereiro de 2013: governo de André Puccinelli, Campo Grande, MS, 2013.

MATO GROSSO DO SUL (Estado). Mensagem à Assembleia Legislativa: governador José Orcírio Miranda dos Santos. Campo Grande, MS, 2000 b.

MATO GROSSO DO SUL (Estado). Plano estadual de educação. Campo Grande, MS: SED/MS, 2004.

MATO GROSSO DO SUL (Estado). Princípios norteadores: a cidadania começa na escola: Plano Estadual de Educação: 1995-1998. Campo Grande, MS: Secretaria de Estado de Educação (SED), 1995.

MATO GROSSO DO SUL (Estado). Resolução SED/MS nº 915, de 20 de janeiro de 1994. Aprova o Regimento Interno do Conselho Estadual de Educação/MS, Campo Grande, MS, 1994.

MATO GROSSO DO SUL (Estado). Resolução SED/MS nº 1.848, de 27 de abril de 2005. Aprova o Regimento Interno do Conselho Estadual de Educação/MS. Campo Grande, MS, 2005.

MATO GROSSO DO SUL (Estado). Resolução/SED n. 2.176, de 30 de maio de 2008. Integra dispositivos à Instrução Normativa n. 1/COGES/SUPED/2008, de 29 de abril de 2008, pertinentes ao Termo de Compromisso - "Educação para o Sucesso/Todos pela Educação". Campo Grande, MS, 2008.

MATO GROSSO DO SUL (Estado). Resolução/SED n. 2.848, de 23 de janeiro de 2014. Aprova o Regimento Interno do Conselho Estadual de Educação/MS. Secretaria de Estado de Educação, Campo Grande, MS, de 23 de janeiro de 2014. Publicado no Diário Oficial n. 8.602 , de 24 de janeiro de 2014 b, p. 15 a 17.

PERONI, V. Conselhos Municipais em tempos de redefinição do conceito de democracia. In: SOUZA, D. B. (Org.). Conselhos Municipais e controle social da educação: descentralização, participação e cidadania. São Paulo: Xamã, 2008. p. 153-168. 
ROCHA, D. A gestão da educação pública em Mato Grosso do Sul: práticas racionalizadoras e clientelismo. Tese (Doutorado em Educação) - Pontifícia Universidade Católica de São Paulo, São Paulo, 1992.

SAVIANI, D. Política e Educação no Brasil: o papel do Congresso Nacional na Legislação do Ensino. São Paulo: Cortez; Autores Associados, 2006. (Educação Contemporânea).

SINGER, P. Ética prática. 2. ed. São Paulo: Martins Fontes, 1998.

\begin{abstract}
Notas
${ }^{1}$ Doutora em Educação. Professora e vice-coordenadora do Programa de Pós-graduação em Educação Mestrado e Doutorado da Universidade Católica Dom Bosco (UCDB), líder do Grupo de Pesquisa Políticas Públicas e Gestão da Educação (GEPPE) e a Linha de Pesquisa Política, História e Gestão da Educação. Email: nadia@ucdb.br

${ }^{2}$ Doutora em Educação pela Unicamp. Pós-doutorado em Ciências da Educação pela Universidade do Minho, Portugal. Docente do Programa de Pós-Graduação em Educação - Mestrado e Doutorado da Universidade Católica Dom Bosco (UCDB). Pesquisadora produtividade CNPq. E-mail: reginacestari@ hotmail.com

${ }^{3}$ Conceitos utilizados por Gramsci (1995), ao definir Estado em sentido ampliado.

${ }^{4} \mathrm{O}$ partido político de o governo militar era a Aliança Renovadora Nacional (ARENA): fundada em 4 de abril de 1966 para apoiar o governo, quando foi instaurado o sistema bipartidário pelo Ato Institucional no 2 , de 27 de outubro de 1965, e pelo Ato Complementar $\mathrm{n}^{\circ} 4$. A ARENA foi extinta em 29 de novembro de 1979, com o fim do bipartidarismo aprovado pelo Congresso Nacional. (RIO DE JANEIRO, 2007).

${ }^{5}$ Essa revogação aconteceu por meio da Emenda Constitucional no ${ }^{\circ} 11 / 1978$.

${ }^{6}$ São os seguintes; Ato Institucional no $1 / 1964$ - cassou o mandato dos políticos de oposição; Ato Institucional $\mathrm{n}^{\mathrm{o}} 2 / 1965$ - extinguiu os partidos existentes e estabeleceu o bipartidarismo; Ato Institucional $\mathrm{n}^{\circ}$ 3/1966 estabeleceu que os prefeitos de capitais, e municípios da área de segurança nacional e os governadores dos estados deveriam ser nomeados pelo governo militar; Ato Institucional no $4 / 1966$ - obrigou o Congresso a votar o projeto da Constituição de 1967; Ato Institucional nº 5/1968 - fechou o Congresso, suspendeu garantias constitucionais e deu poder ao Executivo, poderes legais para legislar sobre todos os assuntos. (BASTOS, 2002).
\end{abstract}

Submetido em: 01/05/2016

Aprovado em: 16/02/2018

Publicado em: 25/04/2018

Rev. HISTEDBR On-line, Campinas, v.18, n.1 [75], p.184-211, jan./mar. 2018 